\title{
SWOT ANALYSIS ON THE TRANSFORMATION OF ISLAMIC HIGHER EDUCATION
}

\section{Muhammad Solihin}

Sekolah Tinggi Agama Islam (STAI) Yasni Muara Bungo

Jl. Lintas Sumatera, KM. 04, Sungai Binjai, Kec. Bathin III, Kab. Bungo, Prov. Jambi, Indonesia 37211

Email: muhammadsolihin@staiyasnibungo.ac.id

\section{Jalaludin}

Universitas Islam Negeri (UIN) Sulthan Thaha Saifuddin Jambi

Jl. Arif Rahman Hakim, No. 111, Simpang IV Sipin, Kec. Telanaipura, Kota Jambi, Indonesia, 36361

Email: jalaludinuinjambi@gmail.com

\section{Mona Novita}

Sekolah Tinggi Agama Islam (STAI) Yasni Muara Bungo

Jl. Lintas Sumatera, KM. 04, Sungai Binjai, Kec. Bathin III, Kab. Bungo, Prov. Jambi, Indonesia 37211

Email: monanovita.staiyasni@gmail.com

\section{Syukri Ismail}

Sekolah Tinggi Agama Islam (STAI) Yasni Muara Bungo

Jl. Lintas Sumatera, KM. 04, Sungai Binjai, Kec. Bathin III, Kab. Bungo, Prov. Jambi, Indonesia 37211

Email: msyukri_ismail@staiyasnibungo.ac.id

Received: 08, 2018. Accepted: 12, 2019. Published: 12, 2019.

\begin{abstract}
The purpose of this study was to analyze the internal and external conditions of STAI (Sekolah Tinggi Agama Islam/Islamic Higher Education) Yasni Muara Bungo in formulating a strategy for changing the form of a higher education institution using TOWS and SPACE Matrix analysis tools as new model of SWOT analysis. This is a case study using a descriptive qualitative method. Data collection techniques were conducted using interviews, surveys and questionnaires. The data obtained were analyzed using TOWS and SPACE matrices. The result of TOWS matrix analysis shows that some alternatives can be applied by STAI Yasni Muara Bungo in changing its form to IAI or Institut Agama Islam (Islamic Institute) Yasni Muara Bungo are the following: (1) Strengthening the input of higher education components (Funding/education costs); (2) Developing of educational/academic, cultural and academic ethics programs in STAI Yasni Muara Bungo; and (3) Improving the quality of the curriculum that is integrated with Islamic elements, global and modern projections. While the results of the SPACE matrix show STAI Yasni Muara Bungo is in the Aggressive quadrant, meaning that it has more dominant strengths and opportunities than weaknesses and threats, making it very possible to be developed into the Islamic Institute of Religion (IAI) Yasni Muara Bungo.
\end{abstract}

Keywords: Higher Institution Transformation, SWOT Analysis, TOWS Matrix, SPACE Matrix

\begin{abstract}
ABSTRAK
Tujuan penelitian ini adalah menganalisis kondisi internal dan eksternal STAI Yasni Muara Bungo dalam merumuskan strategi pada perubahan bentuk. perguruan tinggi dengan alat analisis Matriks TOWS dan SPACE. Metode penelitian yang digunakan adalah deskriptif kualitatif dengan jenis penelitian studi kasus. Teknik. pengumpulan data menggunakan wawancara, survey dan kuesioner. Data yang diperoleh dianalisis menggunakan matriks TOWS dan SPACE. Hasil analisis matriks TOWS menunjukkan alternatifyang dapat diterapkan STAI Yasni Muara Bungo dalam perubahan bentuk menjadi LAI Yasni Muara Bungo adalah (1) Penguatan input komponen perguruan tinggi (Pendanaan/ biaya pendidikan) (2) Pengembangan program pendidikan/akademik, budaya dan etika akademik di STAI Yasni Muara
\end{abstract}


Bungo dan (3) Peningkatan kualitas kurikulum yang terintegrasi unsur keislaman, Proyeksi global dan kemodern. Sementara hasil matriks SPACE menunjukkan STAI Yasni Muara Bungo berada pada kuadran Agresif, artinya memiliki kekuatan dan peluang yang lebih dominan daripada kelemahan dan ancamannya, sehingga sangat memungkinkan untuk dikembangkan menjadi Institut Agama Islam (IAI) Yasni Muara Bungo.

Kata Kunci: Perubaban Bentuk PT, Analisis SWOT, Matriks TOWS, Matriks SPACE

\section{INTRODUCTION}

Indonesia as an open country and part of the international community cannot escape from globalization and it impacts various fields of life. One proof of the government's committment in facing the globalization process is by issuing Regulation of the Minister of Religion of the Republic of Indonesia Number 15 in 2014 concerning Changes in the Form of PTK Perguruan Tinggi Keagamaan/Religious Higher Education). The change in the form of PTK was carried out with the following aims: (a) increasing access to religious higher education, (b) increasing the reach of equity and the spread of higher education and (c) improving the quality and competitiveness of the implementation of religious higher education (Regulation of the Minister of Religion Affair of Republic Indonesia, No. 15, 2015). Given the crucial purpose of changing the shape of a university, educational institutions that have fulfilled the requirements for changing the form of institutions should immediately commence with the process of tranformation, such as from academies to institutes or institutes to universities. One of these institutions is STAI Yasni Muara Bungo.

STAI Yasni Muara Bungo was faced with demands to transform from an academy to institute. This is based on several reasons, including: (1) the urgent needs of the Bungo community for an Islamic University, (2) the need to develop science, technology and art, (3) the diverse study programs at STAI Yasni Muara Bungo, (4) the growth in the number of STAI Yasni Muara Bungo students over the years, (5) the mushrooming of other universities in Bungo Regency, and (6) most of the requirements for submitting institutional changes have been fulfilled (Zaki, 2018). Changes in the form of this higher institution will only be possible if eleven (11) requirements to change the form of higher education as stipulated in the regulation of the Minister of Religion No. 14 of 2014 have been fulfilled by an institution. These components are: the percentage of lecturers'educational qualifications; the percentage of lecturers' academic ranks; the ratio of the number of students and lecturers; the number, types, and variety of study programs; the percentage of educational qualifications of education personnel; the percentage of study program accreditation status; facilities and infrastructure; number of students; community demand; demands in the development of national scientific fields; and development needs (Regulation of the Minister of Religion Affair of Republic Indonesia, No. 15, 2015).

The compulsion of STAI (Perguruan Tinggi Agama Islam/Islamic Higher Education Institutions) Yasni Muara Bungo to make changes, is compatible to what was also conveyed by Abid Hussain et al that schools, colleges, and universities are currently experiencing rapid changes. The progress of innovation, the development of demographics, the expansion of competition, the increase in costs and finance, etc. are the triggers for a change in the shape of a tertiary institution (Ch, et.al., 2016). Similar with Abid Husain above, Agrawal et al., in 2017 also said that one of the main factors in the 21 st century that will undergo a process of rapid change is the fields of economics, science and technology, communication, education, culture, and politics (Agarwal, 2017). Jamshed et al., also stated that universities in the 21st century became more competitive due to modernization and globalization. Even Bunyamin added that the era of globalization was an era of quality competition. So universities in the globalization era should be based on quality. In providing education services and developing human resources, universities should pay attention that excellence is very important at the moment (Bunyamin \& Alamsyah, 2013). Bunyamin also added that the rapid flow of globalization in the third 
millennium made many universities, especially PTAI in Indonesia, often find it difficult to compete, compete and keep up with the times, especially PTAIS (Perguruan Tinggi Agama Islam Swasta/Private Islamic Colleges). In terms of quality PTAIS, it is still far from expectations even many of them are pathetic, namely 'out of business'. Efforts that must be done by universities are to observe and anticipate trends that are happening outside the college, namely the advancement of competitors and the needs of prospective students.

Therefore, STAI Yasni Muara Bungo must know the strengths, weaknesses, opportunities and threats from outside in the face of competition with other universities in Bungo district. Identifying STAI Yasni Muara Bungo's strengths and weaknesses will be very helpful in utilizing every opportunity and avoiding or minimizing threats since in determining competing strategies and making decisions, a manager must recognize what weaknesses, strengths, threats and opportunities that the organization has and recognize the strengths ofexisting competitors (Guiltinan \& Paul, 1991)

One way to analyze aspects of strengths, weaknesses, opportunities and threats in institutions is to do a SWOT analysis (strengths, weaknesses, opportunities and threats). Strengtht $(S)$ is a positive internal condition that provides competitive advantage in the face of competition for educational institutions, for example: educational cost advantages, expertise in producing innovation and sufficient financial resources and superior technology skills. Strength (S) is also an examination of the quality, state or condition expressed by the quality of an association or organization (Ch et al., 2016). Whereas Weaknesses (W) is a negative internal condition that can undermine the assessment of the organization, such as the image of an organization that is still weak, a weak distribution network, the absence of costs in making strategic changes in the organization, lack of clear strategic direction and lack of understanding and knowledgein management related issues. Opportunity $(\mathrm{O})$ is a present or future condition that benefits universities, for example the ability to grow rapidly due to a fairly high increase in market demand, new technologies emerging. While threats $(\mathrm{T})$ are present and future external conditions that will not benefit and can seriously affect the future of educational institutions, such as: the entry of foreign competitors that put lower education costs, the increasing number of similar universities, and regulatory requirements which is quite complicated and expensive (Harray, 2009).

Furthermore (Habimana, Mutambuka, \& Habinshuti, 2018) SWOT analysis as a tool in strategic management is often used as a general method in large companies or in institutions with the aim of building a high-quality strategic analysis matrix. The main purpose of SWOT is to provide marketers with meaningful insights about key organizational competencies after evaluating the data collected through marketing intelligence and to enable them to make the best use of the data in exploiting opportunities, connecting those who have power in the organization, identifying major threats, and minimize weaknesses. In line with Nasri above, Glaister and Falshaw also argue that SWOT analysis is a valuable and prevalent tool in strategic planning. SWOT analysis is also one of several strategic planning tools used by businesses and other organizations to ensure that there are clear objectives for the project or business, and that all factors related to the effort, both positive and negative, are identified and addressed. To complete this task, the process involves four areas of consideration: strengths, weaknesses, opportunities, and threats. It should be noted that, when identifying and classifying relevant factors, the focus is not only on internal problems, but also external components that can have an impact on project success (Osita, 2014). SWOT analysis is a tool used for strategic planning and strategic management in organizations (Gürel, 2017). Thus, it can be concluded that SWOT analysis is a systematic way to identify internal and external factors based on the assumption that effective strategies will maximize strengths and opportunities while minimizing weaknesses and threats (Pearce \& Robinson, 2005) and also useful for determining organizational position 
(Machali \& Hidayat, 2016) which in this case is STAI Yasni Muara Bungo. So that the research on the change in the form of STAI Yasni Muara Bungo to IAI (Institut Agama Islam/Islamic Institution) Yasni Muara Bungo needs to be studied more deeply based on the results of the TOWS and SPACE matrix processing. The TOWS matrix is a simple analytical tool for recording the strengths and weaknesses, opportunities and threats faced by an organization (Heinz Weilrich, 1982). While the SPACE matrix is a SWOT analysis tool which stands for strategic positions and action evaluation. This SPACE analysis tool is used to determine whether the formulation of an organization's strategy is analyzed in the aggressive, conservative, defensive or competitive quadrant. The SPACE matrix has two internal dimensions, namely (financial strength and competitive advantage) and external dimensions, namely (environmental stability and industrial strength)(Steiss, 2003).

In carrying out the analysis, four core questions must have been put in context and the answers will be the starting points for strategy formation. The four questions are: (1) What can we do (strengths and weaknesses)?, (2) What do we want to do (general organizational and personal values)?, (3) What we might do (opportunities and external environmental threats)?, and (4) What do other people expect from what we do? (Sandybayev \& Derkan, 2015). Based on the description above, the objectives in this study are identifying the conditions of internal factors (strengths and weaknesses) of STAI Yasni Muara Bungo, investigating the condition of external factors (opportunities and threats) STAI Yasni Muara Bungo, formulating the STAI Yasni Muara Bungo development strategy to become IAI Yasni Muara Bungo by using the TOWS matrix, and analyzing the possibility of STAI Yasni to change form to IAI Yasni Muara Bungo through the results of SPACE matrix processing. While the research questions that must be answered in this study are the TOWS Matrix analysis result on the transformation of STAI Yasni to IAI Yasni Muara Bungo and the analysis result of the SPACE matrix on the transformation of STAI Yasni Muara Bungo to IAI Yasni Muara Bungo.

\section{METHOD}

The research method used in this study is a qualitative descriptive method. Qualitative approach is research that intends to understand the phenomenon of what is experienced by research subjects such as behavior, perception, motivation, actions holistically and by way of description in the form of words and language, in a special natural context and by utilizing various scientific methods (Lexy J, 2007). This means that an in-depth analysis of the internal and external factors of STAI Yasni Muara Bungo is carried out using qualitative methods.

Data collection techniques used are interview techniques, documentation and observation (survey). From the data collection techniques, the strengths, weaknesses, opportunities and threats of STAI Yasni Muara Bungo were obtained. Once the data were obtained, they were systematically organized in the form of TOWS matrix analysis with the following procedures: (1) identifying weaknesses (internal) and threats (external) that were most urgent to be addressed in general in all components of education, (2) identifying strengths (internal) and opportunities (external) which were expected to be suitable for overcoming weaknesses and threats identified in the first step, (3) formulating recommended strategies for dealing with weaknesses and threats, including problem solving, further improvement and development and (4) determining priorities for handling weaknessesand the threat, and an action plan was developed to carry out the program (admin, 2017). The TOWS matrix correctly analyses internal strengths and weaknesses as well as external threats and opportunities to guide future expected strategies (Farhangi, Hassangholipour, \& Rashidi, 2014). In 1982 Professor Heinz Weinrich published his work offering the TOWS matrix as a new type of SWOT model and saw it as a conceptual framework for systematic analysis of organizations (Weihrich, 1982). On the other hand, the data analysis used the SPACE Matrix analysis tool with the following procedure: (1) scoring the 
four variables seen in an organization, namely (a) financial strength with +1 (worst) score to +6 (Best) consisting of income and expenditure elasticity, organizational cash flow position, (b) competitive advantage with a score of -1 (best) to -6 (worst) which includes user/end user satisfaction, use of technology knowledge, and service quality, (c) environmental Stability with a score of -1 (best) to -6 (worst) such as technological changes and competitive pressures, and (d) industrial strength +1 (worst) to +6 (Best) in the form of financial stability, productivity and technological knowledge; (2) calculate the average score for each dimension; (3) put the plot/average score point of each dimension in cartesian coordinates; (4) read the results of the new intersection; and (5) conclude the organization's position on four criteria namely aggressive, competitive, defensive and conservative (Steiss, 2003).

\section{RESULTS AND DISCUSSION \\ Results of SWOT Analysis with TOWS Matrix}

Environmental analysis consists of an analysis of the internal and external environment is the basis for strategic management. It is called the search for external conditions because only then will the organization be aware of and understand the implications of change to be able to compete more effectively through appropriate policies. Although it seems simple, environmental analysis in reality is very complex. As a result, in the reality that exists, even though the environment has changed so rapidly, so often good ideas in the past are required to become policy guidelines in the present. As well as the mandate that is carried out and continued for tomorrow is certainly with a spirit of difference that is better than the past and better than others (competitors) so that the organization become increasingly competitive (Certo, 2003).

A strategy is a unified, broad and integrated plan that links organizational excellence with environmental challenges and is designed to ensure that the organization's main objectives can be achieved through appropriate implementation by the organization (Lawrence, 2016). Strategy is also a broad basic plan of an organization's actions to achieve its goals (Stanton, Etzel, \& Walker, 2000). A strategy can also be defined an art of using the skills and resources of an organization to achieve its goals through effective relationships with the environment in the most favorable conditions (Salusu \& Salusu, 2008) taking the idea of McNichols). In deciding and formulating a strategy, good management is needed. Strategic management is a set of managerial decisions and actions that determine a company's performance in the long term, including strategy formulation, implementation and evaluation (Hunger \& Wheelen, 2000). Strategic analysis is needed as an important step in the design, construction and selection of effective business strategies. A number of studies provide evidence of the importance of marketing intelligence in effective strategic planning as reported (Caudron, 1994; Huster, 2005).

In the table below are the results of the environmental analysis on STAI Yasni Muara Bungo that the researcher can conclude on table 1.

Table 1. Internal Factors of STAI Yasni Muara Bungo

Strengths (S):

1. STAI Yasni Muara Bungo is the oldest university in Bungo Regency (The Survey results of all seven universities in Bungo District).

2. The variety of Study Programs (7 programs) in STAI Yasni Muara Bungo compared to other universities in Bungo Regency.

3. Education level of Permanent Lecturers of STAI Yasni Muara Bungo: $20 \%$ has a Diploma (S3) or Doctoral degree $(20 \%)$.

4. Great support from the central government for the Scholarship program for underprivileged but outstanding students in STAI YASNI Muara Bungo, such as: (Bidikmisi Scholarship, poor poor scholarship, Bank Muamalat Scholarship, BRIS Scholarship, Tahfiz Scholarship, Governor Scholarship, and Foundation scholarship).

5. The majority of Bungo people are Muslim (337,104 out of 344,100 $=98 \%$ ) (Central Bureau of Statistics, 2016). The Bungo cultural tradition is based on Islamic values marked by the mushrooming of Islamic 
Boarding Schools (30 units) and Private Aliyah Madrasas in Bungo District (19 units) (Religious Data, bungo.kemenag.go.id, 2018).

6. Results of self-evaluation by the Institute of Internal Quality Assurance of the campus show that the high work ethic of most of the STAI Yasni Muara Bungo lecturers has a positive impact on the creation of a conducive academic climate

7. A curriculum that integrates Islamic and modern science by referring to the Indonesian National Qualification Framework (KKNI).

8. The social and religious work market is quite open.

9. Alumni have broad religious knowledge, computer and internet technology skills and good communication skills.

10. The high work ethic of the leaders and staff of STAI Yasni Muara Bungo encourages better academic services.

11. STAI Yasni Muara Bungo curriculum is relevant to the demands and needs of stakeholders because of the availability of Graduates Competency Standards (SKL) for each study program at STAI Yasni Muara Bungo.

12. Campus facilities and infrastructure owned by STAI Yasni Muara Bungo are sufficiently certified with their own property.

13. The spirit and motivation of a strong academic community to carry out community service.
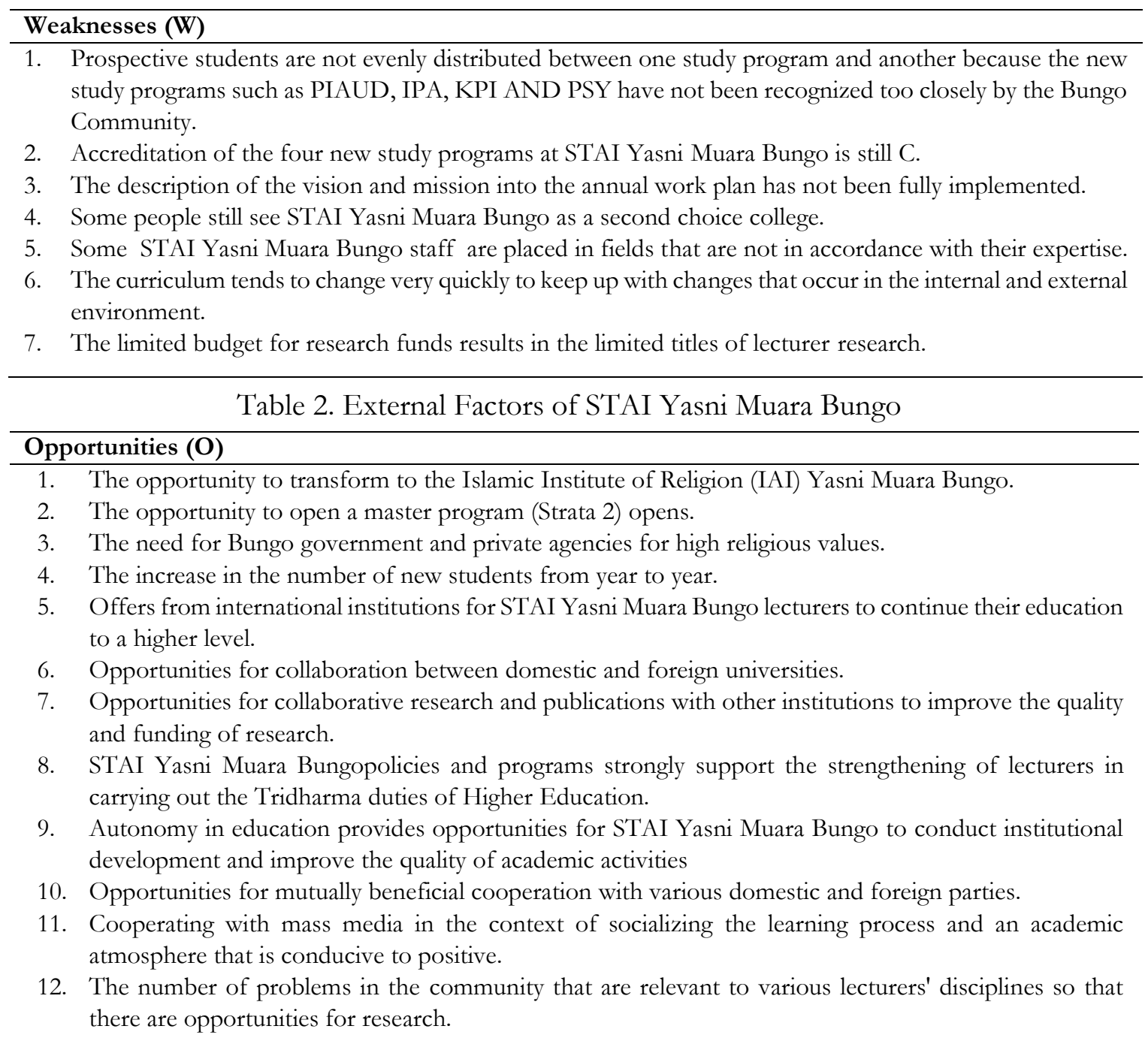


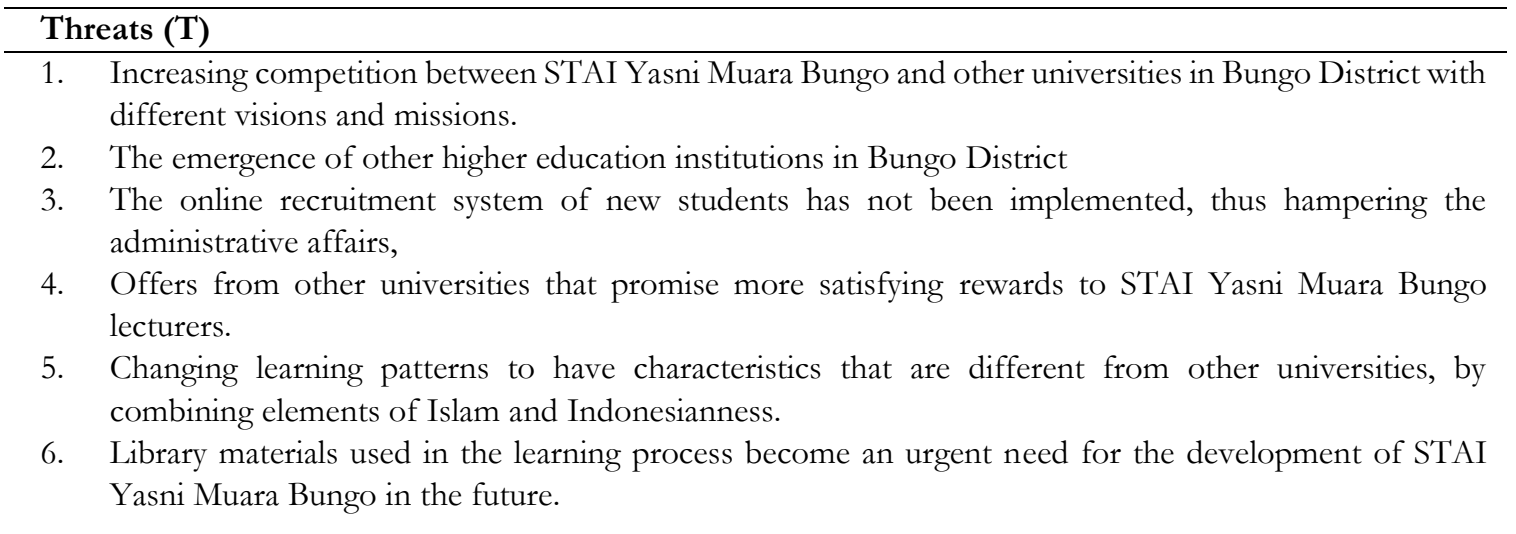

After formulating the external and internal environmental factors of STAI Yasni Muara Bungo, these factors were analyzed using an analysis tool in the form of a TOWS matrix as described in Table 3.

Table 3. Tows Matrix

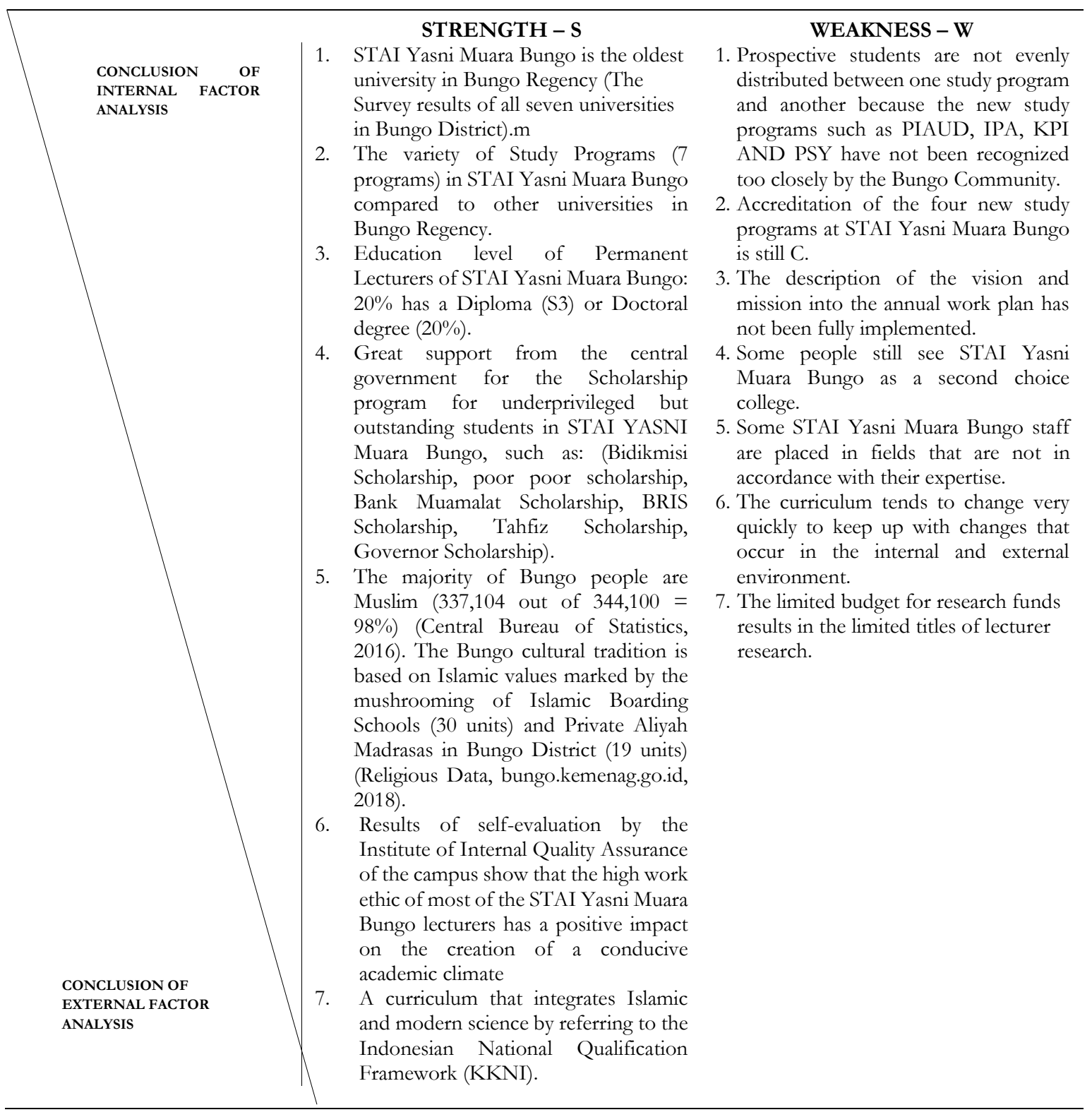




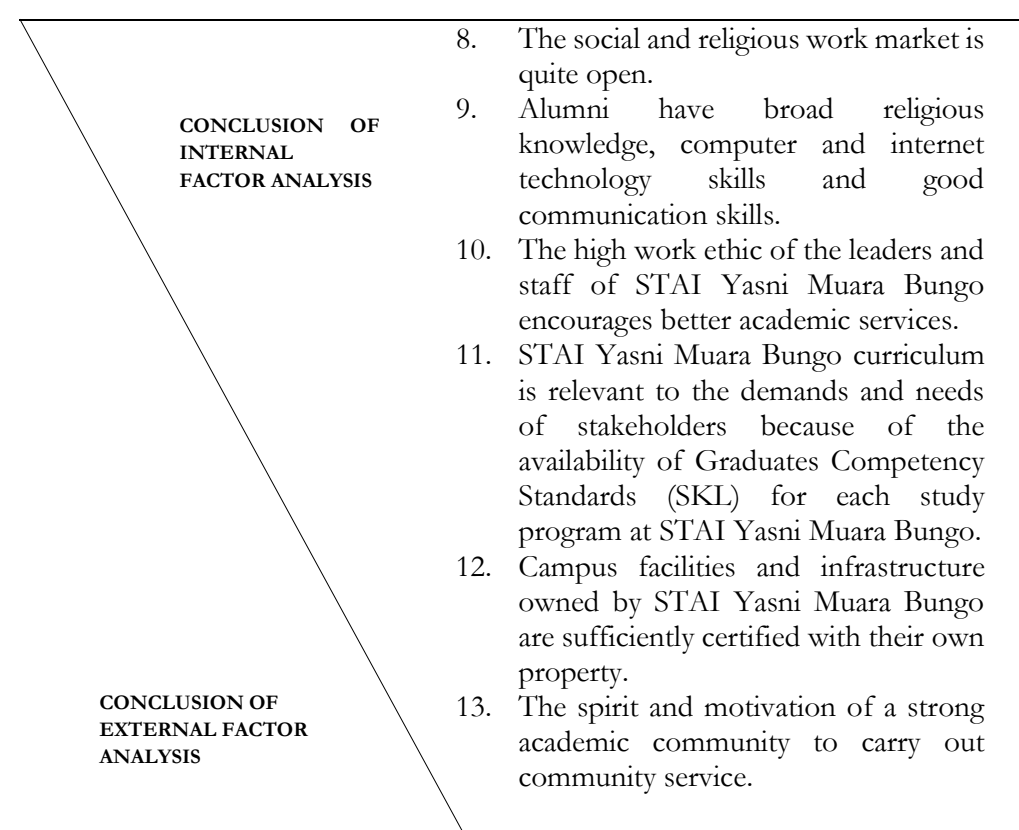

OPPURTUNITIES - O

1. The opportunity to transform to the Islamic Institute of Religion (IAI) Yasni Muara Bungo.

2. The opportunity to open a master program (Strata 2) opens.

3. The need for Bungo government and private agencies for high religious values.

4. The increase in the number of new students from year to year.

5. Offers from international institutions for STAI Yasni Muara Bungo lecturers to continue their education to a higher level.

6. Opportunities collaboration between domestic and foreign universities.

7. Opportunities for collaborative research and publications with other institutions to improve the quality and funding of research.

8. STAI Yasni Muara Bungo policies and programs strongly support the strengthening of lecturers in carrying out the Tridharma duties of Higher Education.

9. Autonomy in education provides opportunities for STAI Yasni Muara Bungo to conduct institutional development and improve
1. STAI Yasni Muara Bungo as the oldest university in Bungo regency, the cheap education costs, huge support from the central government for outstanding scholarship programs for STAI Yasni students and mushrooming of Islamic boarding schools and private Aliyah Madrasas in Bungo District opens the opportunity to transform to IAI Yasni Muara Bungo and also an increase in the number of students only year after year (S1, S2, S5, S6, O1, O4)

2. 2. With the variety of study programs at STAI Yasni Muara Bungo, it opens up the opportunity to transform into IAI Yasni Muara Bungo and establish a Strata 2 / Master of Islamic Education Program so that it can directly fulfill the needs of the Bungo and private government agencies for religious values. (S3, O1, 02, O3)

3. $20 \%$ of of STAI Permanent Lecturers Yasni Muara Bungo has a Doctoral level education so that it opens up the opportunity to transform into IAI Yasni Muara Bungo and form a Strata 2 / Master of Islamic Education Program so that it directly opens opportunities for collaboration between universities (S4, O1, O2, O5)

4. The high work ethic of STAI Yasni Muara Bungo leaders and most of the STAI Yasni Muara Bungo Lecturers has the opportunity to succeed in implementing the Three Principles of Higher Education so that they can enhance the quality of the institution (S7, S11, O8, O9)

5. Islamic integrating Curriculum and modernity opening the opportunities for favourable cooperation with
1. Collaboration with mass media in the context of socialization of Prodi and STAI Yasni Muara Bungo Campus can help even distribution of new students in STAI Yasni Muara Bungo (W1, O12).

2. The opportunity to transform into IAI Yasni Muara Bungo and to open a Masters / S2 program can hasten the accreditation process of existing study programs in STAI Yasni Muara Bungo (W2, O1, O2).

3. With the STAI Yasni Muara Bungo policy and program that strongly supports the strengthening of lecturers in carrying out the Tridharma duties of higher education, it can overcome the inability to explain the vision and mission of STAI Yasni (W3, O8).

4. The opportunity to transform into IAI Yasni Muara Bungo and opening the Starta 2 / Magister program and the high demand of the Bungo government for religious values can overcome / minimize the public's perception that STAI Yasni Muara Bungo is a second-choice college (W4, O1.02, 03).

5. The opportunities for cooperation between universities can overcome the curriculum development that is very fast to follow the changes that occur in the external and internal environment of STAI Yasni Muara Bungo (W6, O6). 


the quality of academic
activities
10. Opportunities for mutually
beneficial cooperation with
various domestic and
foreign parties.
11. Cooperating with mass
media in the context of
socializing the learning
process and an academic
atmosphere that is
conducive to positive.
12. The number of problems
in the community that are
relevant to various
lecturers' disciplines so that
there are opportunities for
research.

\section{THREATS - T}

1. Increasing competition between STAI Yasni Muara Bungo and other universities in Bungo District with different visions and missions.

2. The emergence of other higher education institutions in Bungo District

3. The online recruitment system of new students has not been implemented, thus hampering the administrative affairs,

4. Offers from other universities that promise more satisfying rewards to STAI Yasni Muara Bungo lecturers.

5. Changing learning patterns to have characteristics that are different from other universities, by combining elements of Islam and Indonesianness.

6. Library materials used in the learning process become an urgent need for the development of STAI Yasni Muara Bungo in the future.

7. Strengthening institutional and scientific networks to guarantee the intellectual rights of research results that have not been recognized. various domestic and foreign parties (S8, O10)

6. The availability of campus land that is quite extensive and self-owned, as well as the high desire of the Bungo community for the presence of a Religious College, provides an opportunity is to transform to IAI Yasni Muara Bungo (S13, O1).
1. STAI Yasni Muara Bungo as the oldest university in Bungo regency, The affordable tuition fees at STAI Yasni Muara Bungo, its variety of study programs, the support by STAI Yasni Muara Bungo permanent lecturer education, $70 \%$ of whom have a doctorate (S3), and the amount of central government support and the Bungo government for the Scholarship program for poor students with good achievements in STAI YASNI Muara Bungocan reduce the increasingly fierce competition between STAI Yasni Muara Bungo and other universities that are currently emerging in Bungo Regency (S1, S2, S3, S4, S5, S6, T1, T2).

2. The high work ethic of the leaders and most of the STAI Yasni Bungo Lecturers and the enthusiasm of the education staff can improve the recruitment system of new students at STAI Yasni Muara Bungo (S7, S11, T3)

3. Support from the central government and the Bungo District government can assist in procuring books in the STAI Yasni Muara Bungo library (S5, T6)
1. The good accreditation of the four study programs will reduce competition with other universities in Bungo Regency (W2, T1)

2. The transformation of STAI Yasni Muara Bungo to IAI Yasni Muara Bungo can change the public's view of STAI Yasni as a second-choice university in Bungo Regency (W4, T1)

(Source: Analysis Results of STAI Yasni Muara Bungo Study)

Based on the results of the above research, it is necessary to discuss the follow-up of the strategy formulation that must be carried out by STAI Yasni Muara Bungo in changing its form to IAI Yasni Muara Bungo. Because after determining the direction of the organization in the future (college), it is necessary to formulate a strategy (Suharsaputra, 2016). Strategy formulation 
is the development of long-term plans to effectively manage environmental opportunities and challenges by considering organizational strengths and weaknesses (Hunger \& Wheelen, 2000). Strategy formulation is also the first step in implementing a dynamic strategic management process, which starts from the formulation of strategies, implementation of strategies and evaluation of the success of the strategy (Katsioloudes \& Abouhanian, 2009).

From the SWOT analysis using the TOWS Matrix analysis tool, it is found that there are three (3) strategies that can be used by STAI Yasni Muara Bungo to change its form to IAI Yasni Muara Bungo, namely (a) strengthening the input of Islamic higher education in terms of student tuition (Finance) and academic/curriculum; (b) strengthening of academic culture/culture that integrates Islamic elements/values, global and modern projections, and (c) development of educational/academic programs by paying attention to the quality of lecturers, employees, students and stakeholders.

\section{Strengthening the Input of Islamic Higher Education in terms of Funding/Student Tuition (Finance) and Academic/Curriculum}

Cost and curriculum elements are two (2) of the seven (7) components of a university's self-evaluation (Mahmud, 2012). Both components are classified into the input of education and teaching. The issue of education costs or funds is a classic problem in an organization (syahrizal, 2009). Academic and student development in universities cannot be separated from the university funding. Funding is the lifeblood of a college.

Based on the results of the SWOT analysis at STAI Yasni Muara Bungo, it can be illustrated that STAI Yasni Muara Bungo has been quite capable of strengthening the tertiary input (funding/education costs). Currently, STAI Yasni Muara Bungo is a private Islamic religious college, making foundations, communities and other sources of non-binding institutions/donors as the main source of fund. However, it doesn't mean that the private universities which the fund source is primarily from the community do not mean that the quality of the higher education institutions is lower (syahrizal, 2009). STAI Yasni has a fairly good ability in creating, expanding and exploring new funding sources and managing funds for the benefit of universities in an effective and efficient manner. Some examples are STAI Yasni Muara Bungo making the Nurul Islam Foundation (YASNI), STAI Yasni Muara Bungo alumni strength, STAI Yasni Muara Bungo Lecturer, Grants from Bank collaboration (CSR), Local Government, Provincial Government and Ministry of Religion as the main funding sources for the campus.

Therefore, a number of possible strategies were carried out by STAI Yasni Muara Bungo in terms of strengthening tertiary input (funding/education costs): (a) optimization of research and community service. Currently, STAI Yasni Muara Bungo is struggling to offer research proposals to several ministries and local governments. This is because a quality of research proposal will establish a university as a superior educational institution in terms of university funding; and (b) the development of an entrepreneurship program. The entrepreneurial spirit must be developed so that universities have business units that can generate profits in reviving higher education. Universities that have business units will produce a number of assets and endowments for universities; In this case STAI Yasni Muara Bungo established a student cooperative (KOPMA) and formed a student activity unit (UKM) engaged in entrepreneurship and made entrepreneurship courses as compulsory courses for tertiary institutions and (c) build a network of cooperation with government institutions, the private sector and other parties both at home and abroad. Some examples of collaboration that have been carried out by STAI Yasni Muara Bungo with the government are with the Ministry of Religion, the Bungo District Education Office, the Bungo District Regional Library and Library, the Bungo District Health Office, the Bungo District National Narcotics Agency, the Health Social Security Administration Agency. While the collaboration of STAI Yasni Muara Bungo with private 
parties is through collaboration with the Damandiri foundation, Bank Muamalat KCP Bungo, BRI Syari'ah KCP Bungo, Bungo POS, Jambi Express, Radar Bute, Swarna TV, Gema Bungo, Chandra Public Speaking Management, The Onthel English Course Pare Kediri. The collaboration of STAI Yasni Muara Bungo with abroad is such as the Malacca Islamic University College, Johor Islamic College, the Sultan Idris Malaysian Education University, Asshofa Selangor Islamic College, Sulthan Sharif Ali Islamic University Brunei Darussalam and Kyoto University.

In implementing the strategy to strengthen the input of higher education, STAI Yasni Muara Bungo pay attention to several principles of implementation, namely: accountable nature of funds, which can be accounted for by all sources of funds and carried out transparently, where the public can access some information about higher education funding. Hence people can understand the management and allocation of funds for universities. Transparency also increases the credibility of universities in the eyes of the community (outside parties) (Syahrizal, 2009). Why is transparency an important point here? That is because from the data presented by Rusdiana that the challenges faced by Islamic Universities today, both public (PTAIN) and private (PTAIS) are good governance patterns characterized by transparency and accountability (Rusdiana \& Nasihudin, 2018). It was stated in the results of the study that some of the main problems that hampered the implementation of accountability/accountability in the Private Islamic Religious College (PTKIS) were: (1) management and leadership, (2) curriculum, (3) lecturers, (4) learning process, (5) students, (6) learning facilities, (7) environment, (8) education funds, (9) lecturer ability which is still low in the field of research (Rusdiana \& Nasihudin, 2018). One of the ways undertaken by STAI Yasni Muara Bungo in maintaining accountability of campus funding is to report finances after each work program is held. And that was reported openly in front of the authorities at Yasni Muara Bungo STAI. In addition, STAI Yasni Muara Bungo also conducts financial audits by STAI Yasni Muara Bungo internal audit agency.

Accountability is one of the keys to successful application of higher education because in it there is a guarantee of openness in the management of higher education. With accountability, Islamic higher education will be able to keep pace with the development of the world of education. There is positive feedback from all stakeholders to jointly advance PTAI in which they have mutual interests (Supriadi \& Fasli, 2011). In terms of facilities as one of the factors that hinder the implementation of accountability in tertiary institutions, Fadjar (2005) stated that academic infrastructure and facilities should be prioritized over non-academic facilities and infrastructure, such as libraries, laboratories, the internet, note books and books that are needed by the students teaching staff to always improve their quality and professionalism. As important as facilities and infrastructure, the curriculum element is the heart of education. As James A. Bean stated, Wiiliam H. Schubert quotes Wesley Null in Curriculum from Theory to Practice, that the curriculum is the heart of education. Two reasons why the curriculum can be said as the heart of education, namely: (1) curriculum related to something that should be taught, (2) curriculum is a combination of thoughts, actions and goals (Arifin, 2018). STAI Yasni Muara Bungo ideally designs the curriculum in each study program by referring to academic standards that have become the norm of leading religious' colleges. This method is to ensure that STAI Yasni Muara Bungo graduates are not only superior at the local level, but also capable of being part of the scientific activities of the national and international academic communities. One of the methods undertaken by STAI Yasni Muara Bungo in achieving these goals is by requiring every graduate to master International Languages, namely Arabic and English by taking English courses in Pare village. Likewise, for the mastery of Arabic. 


\section{Strengthening an Academic Culture that is Integrated with Islamic Elements/Values, Global Projection and Modernity}

The academic culture of STAI Yasni Muara Bungo must be able to equip students with knowledge of methodologies that underlie their study program's scientific building and become expert researchers who are able to innovate and generate new ideas and findings. Especially with a very thick Islamic culture, it is hoped that the vision and mission of each study program can be realized. Strengthening academic culture that has Islamic values, is carried out by STAI Yasni Muara Bungo by inserting an Islamic-based curriculum, such as requiring new students to follow the tahsin of the Koran for those who are not yet fluent in reading the Koran, also organizes learning kbl imla, so students can write Arabic well and correctly. These two things are integrated with the Graduate Competency Standards (SKL) that has been made by the STAI Internal Quality Assurance Institute Yasni Muara Bungo. STAI Yasni Muara Bungo also commemorates Islamic holidays, to inculcate Islamic values, promote moderate Islamic studies and not rigid in understanding Islam, balanced studies to form critical reasoning of students so they can determine in carrying out Islam in accordance with Indonesian-ness.

Furthermore, Bunyamin and Alamsyah, (2013) discussed about the concept of culture/academic culture as something that must be empowered, especially related to the potential of the region. The autonomy of higher education management that is more mature while continuing to empower regional potentials is intended so that PTAIS in the regions are able to more freely manage higher education institutions in accordance with regional potentials and opportunities to adjust existing potentials with international potentials that can be developed through international academic networking, so that it will be more able to support the existing PTAIS action to work and prepare everything more optimally. This is assumed because PTAIS in Indonesia as a whole has different characteristics, both public and private and has different regional potentials, as well as problematics as well as problem solving which are certainly very varied. Therefore, campus autonomy policy is an absolute prerequisite that must be done, which of course still considers national interests by always coordinating with the central government (Bunyamin \& Alamsyah, 2013).

\section{Development of Education/Academic Programs by Taking into Account the Quality of Lecturers, Employees, Students and Stakeholders}

The position and strategic role carried out by universities requires that these institutions continuously make changes and improvements in order to improve the quality of higher education. Universities that cannot respond to society will be left behind. Therefore, universities must develop academic programs. The development of education/academic programs at universities cannot be separated from the five pillars of improving university management in Indonesia. The five pillars are: (1) encouraging the implementation of higher education to improve the quality of education, (2) giving autonomy to university implementation, (3) asking university administrators to pay attention to aspects of accountability, (4) carrying out accreditation to all higher education institutions and (5) conduct regular evaluations so that the implementation of education goes as expected (Nandika, 2006).

Academic development efforts can be done through: (a) efforts to strengthen lecturer/employee capacity, (b) utilization of funding, (c) student capacity and (4) other stakeholders. STAI Yasni has done most of the four academic development efforts above, but not all components that have been fulfilled by STAI Yasni, namely third attempt (c) the capacity of students. STAI Yasni has not applied the principle that the new students accepted by their students are only of those who have quality. Additionally, for (d) other stakeholders, STAI Yasni has not fully utilized the role of alumni in improving the quality and competitiveness of universities. Furthermore, STAI Yasni Bungo has not yet fully strengthened the capacity of lecturers, especially if we look at data published by the United Nations Development Program 
(UNDP) showing that in 1996, the quality of Indonesian human resources was ranked 102 out of 174 countries in the world, even in 2007, Indonesia ranked 112th, behind Malaysia (61), Thailand (73), Philippines (84) and Vietnam (108) (Wahyuningrum, 2001). Management that is used in higher education must be regulated in addition to being neat, efficient and transparent, it must also be oriented to meeting academic needs, such as the priority to develop knowledge (SUFYARMA, 2014). The quality of lecturers and the effectiveness of education staff become the main things to improve the competitiveness of higher education, also in terms of improving the competitiveness of college graduates because the quality of college graduates is one indicator to assess the strength of competitiveness of a tertiary institution. The problem that occurs is the lack of quality human resources in tertiary institutions. The lack of commitment from lecturers and education staff is the main key to the lack of competence of university graduates, in addition to curriculum and infrastructure problems (Resmi \& Mekarsari, 2017).

The strategic formulation that the researcher formulated above has fulfilled the criteria for the strategy formulation procedure, that in order to choose an appropriate strategy, the following questions should be answered, namely: (a) Is the strategy chosen in line with the results of the field assessment (evaluation the company/organization?; (b)Does the strategy utilize the strength of the organization?; and (c) Is the strategy chosen in line with the mission of the company/organization and does it achieve the strategic objective? (Montanari, Morgan, \& Bracker, 1990). In addition, it has fulfilled the university management theory, that the organization of higher education must be able to anticipate various policies on several issues, namely: (a) cooperation, (b) compatibility, (c) competitiveness, (d) mobility of students and staff, (e) quality assurance, (f) integrated assurance (transferable credits) and (g) funding mechanisms (Pieter J Vermeulen).

\section{Results of SWOT Analysis with SPACE Matrix Analysis Tool}

The SPACE matrix was analyzed based on the factors of financial strength, STAI Yasni Muara Bungo strength, STAI Yasni Muara Bungo Environmental stability and competitive advantage. The SPACE matrix analysis can be seen in Table 4.

Table 4. SPACE Matrix

\begin{tabular}{ll}
\hline Financial Strength / FS & Score \\
- Great support from the central government for the & 4 \\
scholarship program for outstanding poor students at & \\
STAI YASNI Muara Bungo. & \\
- Enhancing Collaboration with other religious institutions & 4 \\
both at home and abroad & 8 \\
\hline $\begin{array}{l}\text { Industry Strength / IS } \\
\text { - Very cheap education costs without ignoring quality }\end{array}$ & 4 \\
- Variety of Study Programs (Prodi) at STAI Yasni Muara & 4 \\
$\quad$ Bungo with Islamic content, global and modern & \\
projections. & 8 \\
\hline Environmental Stabilities / ES & -2 \\
- High business risk & -3 \\
- The curriculum changes every time & -5 \\
\hline Competitive Advantage / CA & -2 \\
- Relations with other Islamic universities & -1 \\
- The social and religious work market is quite open & -3 \\
Total & \\
\hline
\end{tabular}




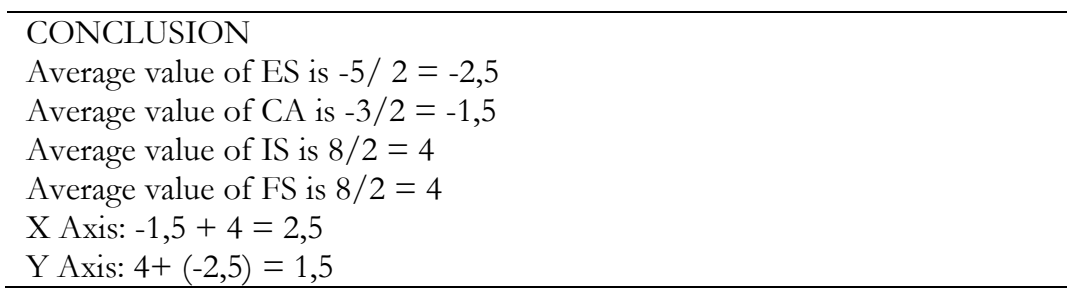

Figure 1. shows the results of the SPACE STAI Yasni Muara Bungo Matrix.

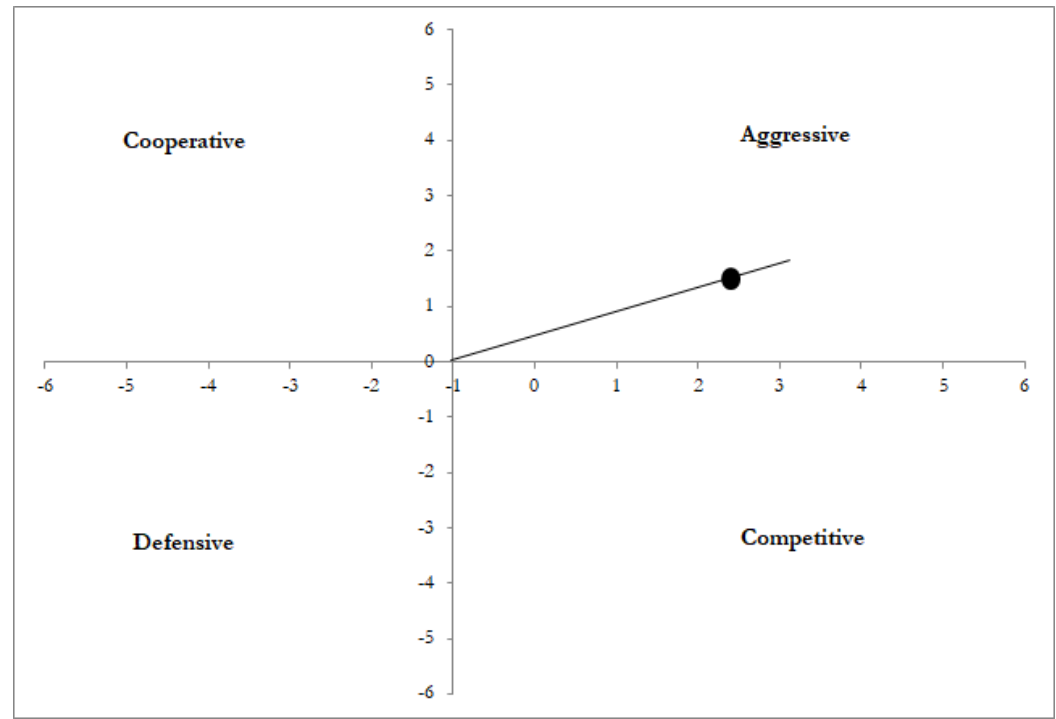

Based on Table 5 and Figure 1 of the SPACE STAI Yasni Muara Bungo Matrix above, it can be seen that the coordinates of the direction vector on the $\mathrm{X}$ axis are 2.5 and on the $\mathrm{Y}$ axis is 1.5. Thus it can be seen that STAI Yasni Muara Bungo is in an aggressive quadrant/growth strategy. Aggressive quadrant/growth strategy is a situation where the strengths and opportunities of the organization are more dominant than its weaknesses and threats. This position can still be studied further to deterimine whether the strengths dominate the opportunities that exist. Evidently, in this position STAI Yasni Muara Bungo must be able to take advantage of various opportunities. Strategies that can be used are (a) strengthening input of Islamic higher education institutions in terms of funding/education and academic/curriculum costs; (b) strengthening existing academic culture/culture that integrates Islamic values, global and modern projections, (c) development of educational or academic programs by taking into account the quality of lecturers, employees, students and stakeholders.

The results of data collection regarding the components of the requirements in the process of changing the form of institutions from academy to institute according to the Minister of Religion Regulation No. 15 in 2014 which have been fulfilled by Yasni Muara Bungo include: (1) the number of study programs is at least 6, while STAI Yasni Bungo already has 7 study programs; (2) the percentage of srata 1 education personnel is at least 60\%; (3) accreditation of the seven study programs is at least $40 \%$ (57\% have been accredited B); (4) the land is more than 100,000 m2; and (5) the number of STAI Yasni Bungo students for the last 5 years is more than 3000 people, namely ( 3779 people). Although not all the requirements are fulfilled by STAI Yasni, but the results of the SWOT analysis with TOWS and SPACE analysis tools can be used as a reference in changing the institution to IAI Yasni Muara Bungo. This is because the SWOT analysis is carried out based on real data/what it is on the field that can be proven during field visitation by the director general of religious higher education. 


\section{CONCLUSION}

STAI Yasni Muara Bungo's main strength lies in: (a) cheaper tuition fees compared to other universities in Bungo Regency, (b) the variety of study programs in STAI Yasni Muara Bungo, (c) curriculum that integrates three values basic, namely Islamic science, general knowledge and global projection as well as natinalism. The results showed that the factor of tuition fees and the variety of study programs in STAI Yasni Muara Bungo was the greatest force that most affected the internal factors of STAI Yasni Muara Bungo, while the opportunities for STAI Yasni Muara Bungo according to the results of the research were the changes in the form of an academyto an Institute, namely from STAI Yasni Muara Bungo to IAI Yasni Muara Bungo. The results of data and information processing using TOWS matrix show that STAI Yasni Muara Bungo should use three strategy formulations, namely (a) strengthening the input of Islamic higher education institutions in terms of funding/education costs and curriculum/academic, (b) strengthening academic culture/culture which integrates Islamic values, global and modern projections, and (c) development of educational/academic programs by improving the quality of lecturers, employees, education personnel, students and stakeholders. While from the results of the analysis using the SPACE Matrix, it is known that STAI Yasni Muara Bungo is in the Aggressive quadrant, meaning that it has more dominant strengths and opportunities than weaknesses and threats, so it is very possible to transform to IAI Yasni Muara Bungo.

\section{BIBLIOGRAPHY}

Admin. (2017, Maret 17). Prof. Dr. Maisah. Retrieved 30 Desember 2019, from Salim Media Indonesia website: http://www.salimmedia.com/prof-dr-maisah/

Agarwal, N. K. (2017). Exploring Context in Information Behavior: Seeker, Situation, Surroundings, and Shared Identities. Morgan \& Claypool Publishers.

Arifin, Z. (2018). Manajemen Pengembangan Kurikulum Pendidikan Islam: Teori dan praktik. Yogyakarta: UIN Sunan Kalijaga.

Bunyamin, B., \& Alamsyah, A. (2013). Manajemen Mutu Perguruan Tinggi Agama Islam Swasta. Jurnal Pendidikan Islam, 28(2), 203-220. https://doi.org/10.15575/jpi.v28i2.544

Caudron, S. (1994). I spy, you spy. Industry Work.

Certo, S. T. (2003). Influencing Initial Public Offering Investors with Prestige: Signaling with Board Structures. The Academy of Management Review, $28(3), 432$. https://doi.org/10.2307/30040731

Ch, A. H., Ahmad, S., \& Khalil, A. (2016). Strengths, Weaknesses, Opportunities and Treats: An Analysis of University of the Punjab. 19.

Fadjar, A. M. (2005). Holistika Pemikiran Pendidikan. Retrieved from http://repository.uinmalang.ac.id/1592/

Farhangi, A., Hassangholipour, T., \& Rashidi, E. (2014). An Empirical Investigation on Factors Influencing Choice of Foreign Market by Media Firms. Management Science Letters, 2, 359362. https://doi.org/10.5267/j.msl.2013.12.016

Guiltinan, J. P., \& Paul, G. W. (1991). Cases in Marketing Management. McGraw-Hill.

Gürel, E. (2017). SWOT Analysis: A Theoretical Review. Journal of International Social Research, 10, 994-1006. https://doi.org/10.17719/jisr.2017.1832

Habimana, T., Mutambuka, D., \& Habinshuti, P. (2018). The Contribution of SWOT Analysis in the Competitiveness of Business Enterprises in Rwanda. Journal of Economics, Business and Management, 6. https://doi.org/10.18178/joebm.2018.6.2.550

Harray, N. (2009). The Challenge of Strategic Management and Strategic Leadership in The Case of Three New Zealand Secondary Schools.

Hunger, J. D., \& Wheelen, T. L. (2000). Strategic Management. Prentice Hall. 
Huster, M. (2005). Marketing Intelligence: A First Mover Advantage. Competitive Intelligence Magarine, 8(2).

Katsioloudes, M., \& Abouhanian, A. K. (2009). Strategic Management. Routledge.

Lawrence, B. A. M. (2016). IPad Acceptance by English Learners in Saudi Arabia. English Language Teaching, 9(12), 34. https://doi.org/10.5539/elt.v9n12p34

Lexy J, M. (2007). Metodologi Penelitian Kualitatif (Revised Edition). Bandung: Rosda Karya.

Machali, I., \& Hidayat, A. (2016). The Handbook of Education Management Teori dan praktik pengelolaan sekolah/madrasah di Indonesia. http://digilib.uin-suka.ac.id/24065/10/BAB\% 208.pdf

Mahmud, M. (2012). Islamic Higher Transformation. Jakarta: Rajawali Press.

Montanari, J. R., Morgan, C. P., \& Bracker, J. S. (1990). Strategic Mmanagement: A Choice Approach. Dryden Press.

Nandika, D. (2006). Pendidikan di Tengah Gelombang Perubahan. Jakarta: LP3ES.

Osita, I. (2014). Organization's Stability and Productivity: The Role of SWOT Analysis an Acronym for Strength, Weakness, Opportunities and Threat. International Journal of Innovative and Applied Research, Volume 2, 23-32.

Pearce, J. A., \& Robinson, R. B. (2005). Strategic Management: Formulation, Implementation, and Control. Boston, Mass: Mcgraw-Hill.

Regulation of the Minister of Religion Affair of Republic Indonesia, No. 15. (2015).

Resmi, N. N., \& Mekarsari, N. K. A. (2017). Pengembangan Perguruan Tinggi Swasta melalui Analisis SWOT. Revitalisasi Tata Kelola Perguruan Tinggi. Presented on Singaraja. Singaraja: P3M Unipas Singaraja.

Rusdiana, A., \& Nasihudin, N. (2018). The Implementation of National Standard-Based Curriculum in Private Islamic Higher Education: Leadership impact. Jurnal Pendidikan Islam, 4(1), 87-98. https://doi.org/10.15575/jpi.v4i1.2116

Salusu, J., \& Salusu, J. (2008). Pengambilan Keputusan Ztratejik: Untuk Organisasi Publik dan Organisasi Nonprofit / J. Salusu; Editor: A. Ariobimo Nusantara. 1. Manajemen ekesekutif 2. Pengambilan keputusan, Pengambilan keputusan stratejik: untuk organisasi publik dan organisasi nonprofit / J. Salusu; Editor: A. Ariobimo Nusantara, 2008(2008), 1-99. https://doi.org/2008

Sandybayev, A., \& Derkan, I. (2015). Correlation SWOT Analysis: A Case of Ercan International Airport in Strategic Business Planning and Management. Diambil dari https://www.academia.edu/10532415/Correlation_SWOT_Analysis_A_Case_of_Erca n_International_Airport_in_Strategic_Business_Planning_and_Management

Stanton, W. J., Etzel, M. J., \& Walker, B. J. (2000). Fundamentos de marketing. McGraw-Hill.

Steiss, A. W. (2003). Strategic Management for Public and nonprofit Organizations. New York: Marcel Dekker.

Sufyarma. (2014). Kapita Selekta Manajemen Pendidikan. Retrived from https://repository.telkomuniversity.ac.id/pustaka/40768/kapita-selekta-manajemenpendidikan.html

Suharsaputra, U. (2016). Manajemen Pendidikan Perguruan Tinggi. Bandung: Rosdakarya.

Supriadi, D., \& Fasli, J. (2011). Reformasi Pendidikan dalam Konteks Otonomi Daerah. Yogyakarta: Depdiknas, Bappenas, Adicita Karya Nusa.

syahrizal, abbas. (2009). Manajemen Perguruan Tinggi. Jakarta: Kencana.

Wahyuningrum, M. (2001). Penerapan Manajemen Berbasis Sekolah dan Desentralisasi Pendidikan Pada Era Otonomi Daerah. (02), 9.

Weihrich, H. (1982). The TOWS Matrix-A Tool for Situational Analysis. Long Range Planning, 15(2), 54-66. https://doi.org/10.1016/0024-6301(82)90120-0

Zaki, M. (2018, Juli 29). Islamic Higher Transformation at STAI Yasni Muara Bungo. 